\title{
Oral Ulceration and Indian Herbs: A Scoping Review
}

\author{
Archna Agnihotri' Antervir Kaur $^{2}$ Rosy Arora ${ }^{1}$ \\ ${ }^{1}$ Department of Pedodontics, Dr. Harvansh Singh Judge Institute of \\ Dental Sciences \& Hospital, Panjab University, Chandigarh, India \\ 2Department of Community Dentistry and Oral Disease Prevention, \\ Eastman Institute of Oral Health, Rochester, New York, \\ United States
}

\begin{abstract}
Address for correspondence Archna Agnihotri, MDS, Department of Pedodontics, Dr. Harvansh Singh Judge Institute of Dental

Sciences \& Hospital, Panjab University, Near UIET, Panjab University

South Campus, Sector 25, Chandigarh 160014, India

(e-mail: archna.agnihotri@gmail.com).
\end{abstract}

Dent J Adv Stud:2020;8:71-79

\begin{abstract}
Keywords

- oral ulcers

- herbal remedies

- traditional medicine

- herbs in dentistry

Oral ulcers are one of the most prevalent oral mucosal diseases. The etiology of oral mucosal ulcers still has to be discerned as a variety of precipitating factors and causes have been implicated. Unless associated with some underlying systemic component, the condition generally takes 10 to 14 days to resolve, sometimes to recur soon. During the active disease phase, it affects eating, drinking and swallowing, thus affecting the quality of life. The treatment is generally symptomatic and is limited to the use of analgesics, antibiotics and topical application of steroids. The use of these over-the-counter drugs can sometimes lead to severe adverse effects. Herbal medicaments provide a safer and efficacious alternative to synthetic drugs. This article aims to review the most commonly used herbal medicines and investigate their efficacy in treating oral ulcers.
\end{abstract}

\section{Introduction}

An oral ulcer is caused by the erosion or loss of the upper mucosal layer. It is one of the most frequently encountered pathological conditions of the oral cavity. These sores are generally painful and are found most frequently on the inside of the lips and cheeks. The etiology of oral ulcers is not yet clear and a variety of conditions are believed to play a role in their occurrence. A variety of viral, fungal, treponemal, autoimmune, nutritional deficiencies, hormonal changes, psychological stress, malignancy and other factors have been implicated in their causation. The nature, site, duration and frequency of oral ulcers are sometimes determined by the underlying systemic condition if any (e.g., inflammatory bowel disease, cyclic neutropenia). ${ }^{1,2}$ Trauma from a sharp tooth or an overhanging restoration, aggressive tooth brushing, smoking crack cocaine, cocaine use or local application of aspirin could also result in ulcer formation. Recurrent aphthous ulcers (RAUs) are the most common form of ulcers among the ulcerative conditions of the oral cavity. Recurrent aphthous stomatitis (RAS) is an acute and extremely painful condition involving nonkeratinized oral mucosa. These ulcers are usually round with a slightly raised margin and surrounded by an erythematous halo. Based on their size and number, these ulcers can be classified into the following ${ }^{3-5}$ :

- Minor ulcers: These are usually small, ranging from 2 to $8 \mathrm{~mm}$ in diameter and may take up to 10 to 14 days to clear up.

- Major ulcers: These are bigger, deeper with raised and irregular borders, often $1 \mathrm{~cm}$ or more. Healing time ranges from several weeks to months.

- Herpetiform ulcers: These are a cluster of smaller ulcers, as small as the size of a pinhead.

Minor aphthous ulcers are the commonest form of aphthous ulcers (80\%) followed by major aphthous ulcers, with the least common being herpetiform ulcers. ${ }^{6,7}$ Ulcerative conditions of the oral cavity have multiple etiologies, but management usually aims at reduction of pain, shortening of duration, prevention of secondary infection and recurrence. The treatment options may involve the use of local anesthetic agents for topical application, systemic and topical steroids, mouth rinses, antibiotics in case of secondary infection, cautery, lasers, or a combination of these. However, frequent use of the medicaments over a prolonged period may lead to fungal infection and development of drug resistance and 
sometimes might even cause severe adverse effects, which can lead to life-threatening consequences. ${ }^{8}$

To find safer alternatives, herbal remedies are being used by herbalists and indigenous healers in many countries for the treatment of ulcers. The rich heritage of our native herbal medicine is now getting global attention. Various herbs such as Azadirachta indica (neem), aloe vera gel, turmeric and licorice have been used since time immemorial for the treatment of mouth ulcers. The research has shown that the basis of the pharmacological and healing properties of herbs is naturally present biologically active compounds such as flavonoids, tannins and gums. ${ }^{9}$ Clinical studies on the use of herbs have shown promising results in terms of reduction in size, discomfort, duration and recurrence of ulcers. Prolonged use of herbal medicaments is also considered safe and efficacious. ${ }^{10-13}$

Although herbal medicines are widely used and numerous studies have been conducted in this regard, there is no consensus on the medicament of choice for the treatment of oral ulcers. This review is aimed at compiling a set of herbs with antiulcer properties and to help extend the application of principles of holistic healing in dentistry.

\section{Materials and Methods}

The literature review was started with a defined background to review the studies involving interventions using herbal medicaments for mouth ulcers. The review was conducted using electronic databases PubMed, Google Scholar, Cochrane Database, Science Direct, Springer Link, and Scopus. The articles published in English from the year 1985 to March 2020 were screened for clinical trials conducted to evaluate the efficacy of herbal drugs in treating oral ulcers. The search strategy involved the use of the following keywords: "herbs," "plants," medicinal plants," "herbal compounds," "herbal remedies," "Indian herbs," "oral ulcers," and "mouth ulcers." The studies were selected using the previously described protocol titles and abstracts of clinical trials were then screened. The full-texts of relevant studies were read independently. References of selected studies were then hand-searched to find relevant studies that might have been missed. - Table 1 describes the form and dosages of various herbs from the clinical trials used for the treatment of oral ulcers.

\section{Discussion}

The major reason for a growing trend towards the preferred use of traditional and alternative therapy for various diseases is people getting more proactive towards prevention and selfcare. Recently, there has been a surge in the sales of products labeled as natural and herbal, but the marketing strategy behind it implying "natural means safe" may not always turn out to be true. Although herbal products are safe and have negligible adverse effects, there are several case reports of overdose and unintentional injuries caused by unqualified practitioners using herbal products. ${ }^{38}$ The focus of scientific drug research has always been on the drugs of synthetic origin. Lack of a sufficient number of high-quality evidence-based clinical trials, standardization of drugs, presence of heavy metals, undisclosed source of the herb, licensing, formulation, composition, labeling and quality control are the reasons being quoted since years against the use of herbal drugs in India. Companies abroad are spending millions of dollars on research to obtain patents for our traditional herbal medicines. The safety profile of natural products, especially herbal medicines as compared to their synthetic counterparts is the main reason behind their increasing popularity amongst the researchers in recent decades. Treatment for oral ulcers has always been challenging. The herbal medicine could emerge as one of the best alternative options for the management of mouth ulcers due to naturally occurring tannins, quinones, flavones, flavonoids and gallic acid constituents. ${ }^{39} \mathrm{~A}$ spectrum of medicinal properties of these herbs such as being anti-inflammatory, antiseptic, antibacterial, antiviral, antimicrobials, antifungal, analgesic and anti-plaque altogether make these herbs a one-stop solution for almost all kinds of ulcers with different or unknown etiologies. They act by maintaining a healthy microbiome, reducing microbes and improving immunity underway, thus preventing oral dysbiosis and recurrence. Various clinical trials have also shown the herbs to be effective in terms of decreasing pain intensity, lesion diameter, erythema and exudation compared with that of the control group..$^{14,40}$

Research trials are now also being conducted to incorporate herbs in different drug delivery systems such as oral patches, dissolvable patches, bioadhesive patches, gels, mucoadhesive films and mouthwashes for the delivery of natural remedies at the site and increase their substantivity. . $^{15,41,42}$ The mucoadhesive systems help in prolonging the duration of action at the ulcer site by increasing the contact time of the drug with mucous membrane and thus the bioavailability. Also, mucoadhesive system along with stimuli-sensitive drug delivery approach using thermoreversible polymers has been found to improve the effectiveness of the drugs and patient compliance. ${ }^{42}$

A comprehensive review of trials conducted to evaluate the clinical efficacy of natural herbs and synthetic over-thecounter drugs for the treatment of oral ulcers is as follows.

\section{Turmeric (Curcumin)}

The most active constituent and major curcuminoid found in turmeric is curcumin. Various medicinal properties listed for curcumin are analgesic, antioxidant, antiseptic, antibacterial, anti-inflammatory and immunomodulatory. Clinical trials have proved its effectiveness in treating RAS as well as radiation-induced oral mucositis. ${ }^{17,18,43,44}$ Curcumin inhibits biosynthesis of inflammatory prostaglandins, which is responsible for its anti-inflammatory properties. ${ }^{14}$

Daddy et a ${ }^{15}$ compared turmeric with triamcinolone for the treatment of minor oral RAS and both were found to have similar effectiveness in alleviating pain and reducing the ulcer size. The authors concluded that turmeric can be used for treating minor RAS, meanwhile triamcinolone cannot be advocated for the long-term management of oral ulcers. 
Oral Ulcerations and Herbal Remedies Agnihotri et al. 73

Table 1 Herbs for oral ulcers: form and dosages used in clinical trials

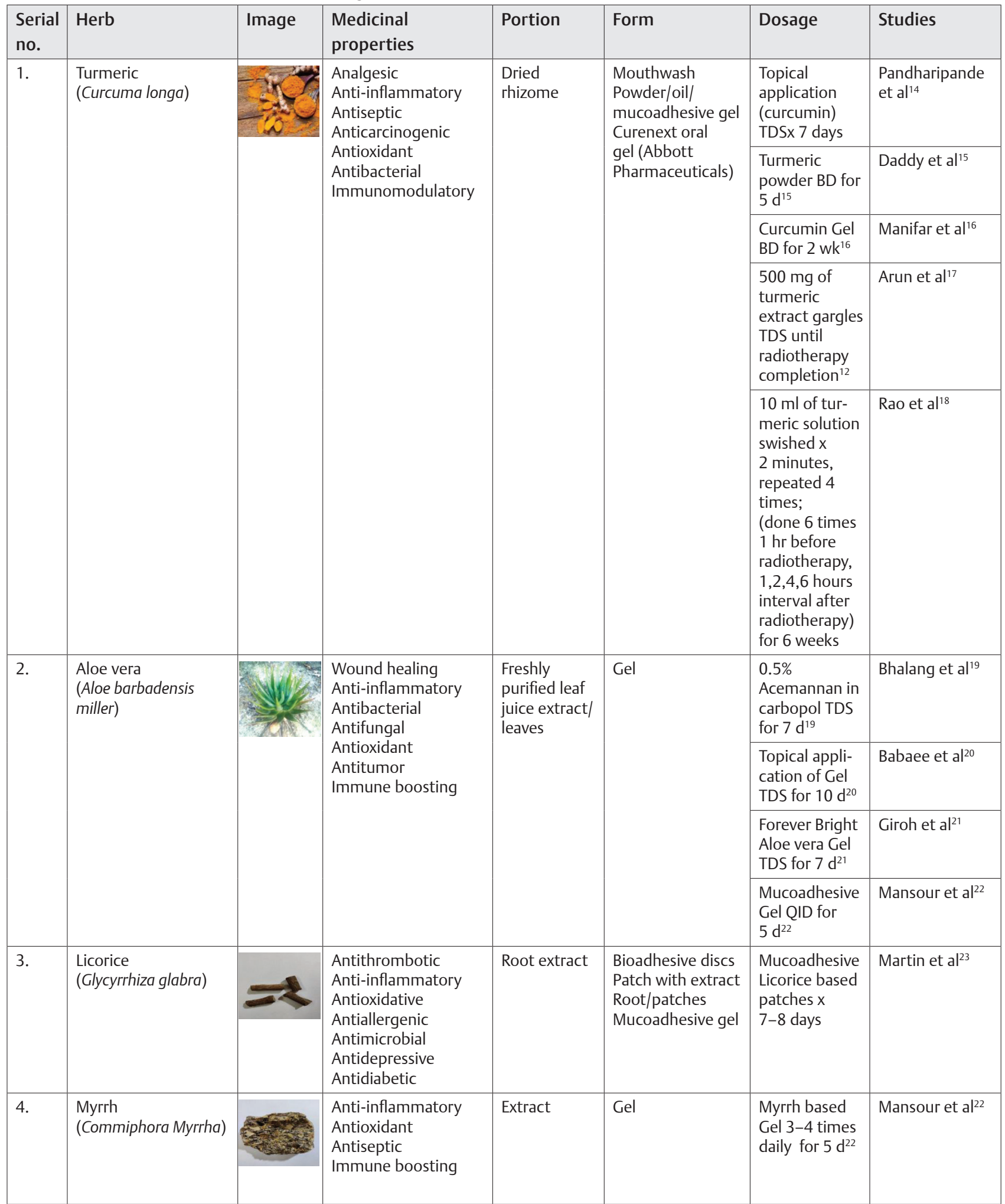

(Continued) 
Table 1 (Continued)

\begin{tabular}{|c|c|c|c|c|c|c|c|}
\hline $\begin{array}{l}\text { Serial } \\
\text { no. }\end{array}$ & Herb & Image & $\begin{array}{l}\text { Medicinal } \\
\text { properties }\end{array}$ & Portion & Form & Dosage & Studies \\
\hline \multirow[t]{6}{*}{5.} & \multirow[t]{6}{*}{ Honey } & \multirow{6}{*}{$\sum_{1 \rightarrow \infty}^{\infty}$} & \multirow{6}{*}{$\begin{array}{l}\text { Antibacterial } \\
\text { Anti-inflammatory } \\
\text { Immune boosting } \\
\text { Antifungal }\end{array}$} & \multirow[t]{6}{*}{$\begin{array}{l}\text { Gel/ } 100 \% \\
\text { pure natural } \\
\text { honey }\end{array}$} & \multirow[t]{6}{*}{$\begin{array}{l}\text { Honey and tulsi } \\
\text { ice chips }\end{array}$} & $\begin{array}{l}\text { Topical } \\
\text { application } \\
\text { TDS for } 5 \mathrm{~d}^{24}\end{array}$ & Halim et al ${ }^{24}$ \\
\hline & & & & & & $\begin{array}{l}\text { Topical appli- } \\
\text { cation QID for } \\
5 \mathrm{~d}^{25}\end{array}$ & $\begin{array}{l}\text { El-Haddad } \\
\text { et } \mathrm{al}^{25}\end{array}$ \\
\hline & & & & & & $\begin{array}{l}\text { Swish honey } \\
\text { tulsi ice chips } \\
5 \text { mins before } \\
\text { the each dose } \\
\text { of methotrex- } \\
\text { ate; Replenish } \\
\text { chips before } \\
\text { previous ice } \\
\text { has melted x } \\
30 \text { mins }\end{array}$ & $\begin{array}{l}\text { Mishra and } \\
\text { Nayak }^{26}\end{array}$ \\
\hline & & & & & & $\begin{array}{l}\text { Topical } \\
\text { application } \\
\text { TDS for } 7 \mathrm{~d}^{14}\end{array}$ & $\begin{array}{l}\text { Pandharipande } \\
\text { et al }{ }^{14}\end{array}$ \\
\hline & & & & & & $\begin{array}{l}\text { Local } \\
\text { Application } \\
\text { TDS for } 3 \mathrm{~d}^{27}\end{array}$ & $\begin{array}{l}\text { Mohamed and } \\
\text { Al-Dourii27 }\end{array}$ \\
\hline & & & & & & $\begin{array}{l}\text { Rinse and } \\
\text { swallow } 20 \mathrm{ml} \\
\text { pure honey } \\
15 \text { mins } \\
\text { before, } \\
15 \text { mins and } \\
6 \text { hrs after the } \\
\text { radiation }\end{array}$ & $\begin{array}{l}\text { Motallebnejad } \\
\text { et } \mathrm{al}^{28}\end{array}$ \\
\hline 6. & Propolis (bee glue) & $x=8$ & $\begin{array}{l}\text { Anti-inflammatory } \\
\text { Antioxidant } \\
\text { Immunostimulant } \\
\text { Wound healing } \\
\text { Antibacterial } \\
\text { Antiviral } \\
\text { Antifungal } \\
\text { Antitumor }\end{array}$ & Beewax/resin & $\begin{array}{l}\text { Oromucoadhesive } \\
\text { films/ } \\
\text { Capsule/paste }\end{array}$ & $\begin{array}{l}2 \mathrm{~cm}^{2} \\
\text { mucoadhesive } \\
\text { film for } 20 \mathrm{~s} \\
\text { BD for } \\
10 \text { days }^{29}\end{array}$ & Arafa et a ${ }^{29}$ \\
\hline 7. & $\begin{array}{l}\text { Lady mantle } \\
\text { (Alchemilla vulgaris) }\end{array}$ & & Wound healing & $\begin{array}{l}\text { Extract + } \\
\text { glycerin }\end{array}$ & 3\% Aphtarine gel & $\begin{array}{l}\text { Topical appli- } \\
\text { cation TDS for } \\
2-3 d^{31}\end{array}$ & $\begin{array}{l}\text { Shrivastava and } \\
\text { John }\end{array}$ \\
\hline 8. & $\begin{array}{l}\text { Echinacea } \\
\text { (Echinacea purpurea) }\end{array}$ & & $\begin{array}{l}\text { Anti-inflammatory } \\
\text { Common cold } \\
\text { Respiratory tract } \\
\text { Infection viruses } \\
\text { Ulcers such as } \\
\text { syphilis } \\
\text { Abscesses ulcers } \\
\text { Swelling of the tonsils }\end{array}$ & Echinacea & Liquid/tablets & $\begin{array}{l}\text { Immustin } \\
\text { Tablets- Three } \\
\text { tablets in a } \\
\text { day for } 5 \mathrm{wk}^{32}\end{array}$ & $\begin{array}{l}\text { Khozeimeh } \\
\text { et } a^{32}\end{array}$ \\
\hline 9. & $\begin{array}{l}\text { Guava } \\
\text { (Psidium guajava) }\end{array}$ & & $\begin{array}{l}\text { Antioxidant } \\
\text { Antibacterial } \\
\text { Anti-inflammatory } \\
\text { Anticancer } \\
\text { Antifungal } \\
\text { Antimicrobial } \\
\text { Antitumor } \\
\text { Antiallergic } \\
\text { Antihyperglycemic } \\
\text { Antimutagenic }\end{array}$ & Leaves & $\begin{array}{l}\text { Leaves/powder/ } \\
\text { gel/guava leaves } \\
\text { mouthwash }\end{array}$ & $\begin{array}{l}\text { Gargle } 250 \mathrm{~mL} \\
\text { for } 3 \text { min TDS } \\
\text { for } 7 \mathrm{~d}^{33}\end{array}$ & $\begin{array}{l}\text { Guintu and } \\
\text { Chua }^{33}\end{array}$ \\
\hline
\end{tabular}


Table 1 (Continued)

\begin{tabular}{|c|c|c|c|c|c|c|c|}
\hline $\begin{array}{l}\text { Serial } \\
\text { no. }\end{array}$ & Herb & Image & $\begin{array}{l}\text { Medicinal } \\
\text { properties }\end{array}$ & Portion & Form & Dosage & Studies \\
\hline \multirow[t]{2}{*}{10.} & \multirow[t]{2}{*}{$\begin{array}{l}\text { Chamomilla } \\
\text { (Matricaria } \\
\text { Chamomilla) }\end{array}$} & & \multirow{2}{*}{$\begin{array}{l}\text { Anti-inflammatory } \\
\text { Antibacterial } \\
\text { Antifungal } \\
\text { Antiviral } \\
\text { Analgesic } \\
\text { Antispasmodic } \\
\text { Smooth muscle-relax- } \\
\text { ing action }\end{array}$} & \multirow[t]{2}{*}{ Fluid extract } & \multirow{2}{*}{$\begin{array}{l}\text { Tincture } \\
\text { mouthwash } \\
\text { Ointment } \\
\text { Strong tea made } \\
\text { from chamomile } \\
\text { flowers }\end{array}$} & $\begin{array}{l}\text { Chamomile } \\
\text { tincture } \\
10 \text { drops TDSx } \\
6 \text { days }\end{array}$ & Seyyedi et $a^{34}$ \\
\hline & & & & & & $\begin{array}{l}\text { Chamomile } \\
\text { tea three to } \\
\text { four times per } \\
\text { day }^{2}\end{array}$ & Subiksha² \\
\hline 11. & $\begin{array}{l}\text { Ginger } \\
\text { (Zingiber officinale) }\end{array}$ & & $\begin{array}{l}\text { Anti-inflammatory } \\
\text { Antinausea } \\
\text { Digestion aid } \\
\text { Antioxidant } \\
\text { Metabolism }\end{array}$ & $\begin{array}{l}\text { Ginger's } \\
\text { Alcoholic } \\
\text { Extract. }\end{array}$ & $\begin{array}{l}\text { Mucoadhesive } \\
\text { Base }\end{array}$ & $\begin{array}{l}\text { Daily for } 20 \\
\text { min after } \\
\text { every meal } \\
\text { and before } \\
\text { going to bed } \\
\text { for } 7 \mathrm{~d}^{35}\end{array}$ & $\begin{array}{l}\text { Haghpanah } \\
\text { et } a^{35}\end{array}$ \\
\hline 12. & $\begin{array}{l}\text { Triphala } \\
\text { (Emblica officinalis, } \\
\text { Terminalia bellirica, } \\
\text { Terminalia chebula) }\end{array}$ & & $\begin{array}{l}\text { Antibacterial } \\
\text { Antifungal } \\
\text { Antiviral } \\
\text { Antioxidant } \\
\text { Diabetes }\end{array}$ & Extract & $\begin{array}{l}\text { Mouthwash } \\
\text { Mixed with } \\
\text { honey for local } \\
\text { application }\end{array}$ & $\begin{array}{l}10 \mathrm{~mL} \text { twice } \\
\text { daily } \times 30 \mathrm{~s} \times \\
7-21 \mathrm{~d} \text { as an } \\
\text { antimicrobial } \\
\text { mouthwash }\end{array}$ & Sen et $\mathrm{al}^{36}$ \\
\hline 13. & $\begin{array}{l}\text { Tulsi } \\
\text { (Ocimum sanctum/ } \\
\text { holy basil) }\end{array}$ & & $\begin{array}{l}\text { Anti-inflammatory } \\
\text { Antioxidant } \\
\text { Antibacterial } \\
\text { Immunomodulatory } \\
\text { Analgesic } \\
\text { Anticancer } \\
\text { Antiasthmatic } \\
\text { Antidiabetic } \\
\text { Hepatoprotective }\end{array}$ & Leaves & $\begin{array}{l}\text { Honey and tulsi } \\
\text { ice chips }\end{array}$ & $\begin{array}{l}\text { Swish honey } \\
\text { tulsi ice chips } \\
5 \text { mins before } \\
\text { the each dose } \\
\text { of methotrex- } \\
\text { ate; Replenish } \\
\text { chips before } \\
\text { previous ice } \\
\text { has melted x } \\
30 \text { mins }^{36}\end{array}$ & $\begin{array}{l}\text { Mishra and } \\
\text { Nayak }^{26}\end{array}$ \\
\hline 14. & $\begin{array}{l}\text { Neem } \\
\text { (Azadirachta indica) }\end{array}$ & & $\begin{array}{l}\text { Anti-inflammatory } \\
\text { Antihyperglycemic } \\
\text { Antiulcer } \\
\text { Antifungal } \\
\text { Antibacterial } \\
\text { Antiviral } \\
\text { Antioxidant } \\
\text { Antimutagenic } \\
\text { Anticarcinogenic }\end{array}$ & Leaves & Oil & $\begin{array}{l}10 \mathrm{~mL} B D \text { for } \\
10 \mathrm{~d}^{37}\end{array}$ & Lahankar et al $\left.\right|^{37}$ \\
\hline
\end{tabular}

Abbreviations: BD, two times a day; QID, four times a day; TDS, three times a day.

Deshmukh and Bagewadi ${ }^{42}$ conducted a randomized clinical trial comparing the efficacy of curcumin with that of triamcinolone acetonide for the treatment of minor RAS. A significant difference was found in terms of reduction of size, pain intensity, duration and number of lesions in both the groups. No allergic reactions were reported for both of these gels.

Manifar et al ${ }^{16}$ in a similar randomized, placebo-controlled trial compared curcumin gel to placebo for the treatment of minor aphthous ulcers. It was found that the use of curcumin gel resulted in a definite reduction in the pain intensity and the size of the lesion as compared with the placebo.

Pandharipande et a $\mathbf{l}^{14}$ concluded from their study that curcumin was slightly more effective than honey for the treatment of aphthous ulcers and that both honey and curcumin could be used as an alternative treatment modality in the management of RAS.

\section{Aloe Vera (Aloe barbadensis)}

Aloe vera gel is known to contain anthraquinones, vitamins, choline, folic acid, amino acids and minerals. Aloe has shown to have anti-inflammatory, antiviral, antitumor, antiseptic, moisturizing and healing properties and has been used in the management of RAS, herpes simplex and herpes zoster infection. ${ }^{19,45-47}$

Babaee et $\mathrm{a}^{20}$ conducted a clinical trial to evaluate the therapeutic effects of aloe vera gel and found that $2 \%$ oral gel effectively decreased not only the wound size and pain score but also the duration of healing in patients with minor RAS.

In a double-blind, randomized clinical trial, the use of aloe vera gel and $0.12 \%$ chlorhexidine (CHX) gel was evaluated for the prevention of traumatic ulcers in patients with fixed orthodontic appliances. At the end of the study, aloe vera was 
found to provide better results than CHX gel with no adverse effects. The authors concluded that aloe vera gel could be used as an effective preventive measure for traumatic ulcers during fixed orthodontic treatment. ${ }^{48}$

Giroh et $\mathrm{al}^{21}$ did a comparative evaluation of aloe vera and triamcinolone acetonide $0.1 \%$ (Kenacort) in the management of RAS and found Kenacort paste to be more effective than aloe vera gel in decreasing the ulcer size. In contrast, aloe vera gel had a better response in terms of pain reduction and burning sensation. The authors concluded that aloe vera could emerge as a promising agent in treating oral lesions, especially for patients who are allergic to steroid medications.

Another randomized double-blind, vehicle-controlled study compared the clinical effectiveness of aloe vera and myrrh-based oral mucoadhesive gels in the management of minor RAS. It was observed that aloe vera performed better at decreasing ulcer size, erythema, and exudation, whereas myrrh was better at pain reduction. ${ }^{22,49}$

\section{Licorice (Glycyrrhiza glabra)}

An active ingredient found in licorice root is glycyrrhiza extract, which has anti-inflammatory properties and is used to calm and soothe the affected area. Licorice has been found to be effective in the treatment of herpes labialis and radiation-induced mucositis. ${ }^{50,51}$ Recent research has suggested that licorice due to its bioactive ingredients such as glycyrrhizin, glabridin, licochalcone $\mathrm{A}$, licoricidin, and licorisoflavan $A$ has specific potential for treating oral diseases. ${ }^{52}$

Martin et $\mathrm{al}^{23}$ conducted a clinical trial to compare the effect of glycyrrhiza herbal extract in dissolving oral patch and placebo on aphthous ulcers and found that there was $90 \%$ reduction in the ulcer size as compared with $68.5 \%$ in the placebo group.

Moghadamnia et $\mathrm{al}^{53}$ evaluated licorice bioadhesive hydrogel patches for their efficacy in pain control and effect on the healing time of RAU. The authors found that licorice bioadhesive was effective in reducing the pain intensity and decreasing the inflammatory halo as well as the necrotic center of aphthous ulcers. Although the results were not found to be statistically significant.

\section{Purple Cone Flower (Echinacea purpurea)}

The chemical components of Echinacea plant such as alkaloids, polysaccharides, and chicoric acid have immunomodulatory and anti-inflammatory properties. ${ }^{54-57}$ Khozeimeh et $\mathrm{a}^{32}$ studied the effectiveness of Echinacea when taken in the form of tablets on aphthous ulcers. The drug reduced the number of lesions, pain intensity, improved healing and increased the duration between the recurrences. These effects were similar to prednisolone and colchicine (hastened healing and reduced pain) but fewer as compared with them.

\section{Honey}

Honey results in an increased rate of tissue regeneration and suppression of inflammation, edema, exudation and malodor in wounds as evidenced in various clinical observations and trials. ${ }^{27,43,58}$ Halim et $\mathrm{al}^{24}$ in their study found that local application of honey was effective in treating minor RAS. It was found to have a comparable effect to that of salicylate gel. Authors thus concluded that honey could be used as an alternative treatment of oral ulcers for their patients since honey is available worldwide and cheaper.

El-Haddad et $\mathrm{a}^{25}$ in a parallel, blinded, randomized controlled trial compared the clinical efficacy of topical corticosteroid treatment with that of honey for the management of recurrent minor aphthous stomatitis and found that honey was an effective and safe option in reducing the intensity of pain, ulcer size, and erythema.

A study also compared cryotherapy treatment in pediatric oncology patients using flavored ice cubes (honey and tulsi) and plain ice cubes. It was found that flavored ice cubes were more effective than plain ice cubes in the reduction of oral mucositis in the patient receiving methotrexate. They concluded that flavored ice cubes can be incorporated into routine practice in pediatric oncology in patients undergoing chemotherapy to prevent occurrence. ${ }^{26}$

In another randomized single-blind clinical trial, Motallebnejadet $\mathrm{al}^{28}$ concluded that the topical application of natural honey is effective in managing radiation-induced mucositis.

\section{Bee Glue (Propolis)}

The propolis extract has anti-inflammatory, antimicrobial, antioxidant, immuno-stimulant, and wound healing activities. ${ }^{59,60}$

Arafa et $\mathrm{al}^{29}$ evaluated the effect of oromucoadhesive films of propolis on aphthous ulcers. It was found that the application of propolis films resulted in reduction in ulcer size, prolonged duration of pain relief and reduced healing time in patients with RAUs, which ultimately resulted in a very high level of patient satisfaction, proving the success of this new drug delivery system.

The study by Samet et al ${ }^{30}$ also proved that propolis was effective in preventing recurrence of lesions and improving the quality of life in patients suffering from RAS.

Heyam and Rasool ${ }^{40}$ evaluated the use of olive oil based propolis paste for patients with RAU. It was observed that olive oil based propolis formula was significantly more effective in reducing the size of the lesion, duration for complete healing, pain and bioadhesion time to the buccal mucosa as compared with sesame-based formula and the placebo formula. No allergic reaction or any other side effects were observed with its use. It was found to be stable and free of microorganisms for over 6 months of storage. 


\section{Lady Mantle (Alchemilla vulgaris)}

Shrivastava and John ${ }^{31}$ in their open label study on lady mantle (Alchemilla vulgaris) revealed that topical application of Aphtarine gel (commercial preparation of Alchemilla vulgaris in glycerin) on minor mouth ulcers reduced discomfort and helped in achieving complete healing in majority of patients within 3 days period; no adverse effects were reported. The authors concluded that Aphtarine is safe, well-tolerated, and highly effective, promising new treatment for healing oral ulcers.

\section{Guava (Psidium guajava)}

Psidium guajava has been used for the herbal management of various oral diseases such as toothache, sore throat, and inflamed gums, and ulcers. A decoction of guava leaves also has been used as mouthwash. ${ }^{61}$ Shaikh et al and Thombre et al in two different studies formulated and evaluated aqueous gel of powdered guava leaves for mouth ulcer treatment and observed that powdered guava leaves contained flavonoids and showed a significant antioxidant effect. The herbal formulation was found to be stable, safe and effective as compared with synthetic formulations for the treatment of mouth ulcers. ${ }^{13,62}$

Guintu and $\mathrm{Chua}^{33}$ in their randomized prospective open label clinical study found that guava leaves mouthwash was effective in reducing the pain intensity and resulted in faster healing of aphthous ulcers.

\section{Chamomile (Matricaria chamomilla)}

Chamomile is one of the most ancient medicinal herbs. The dried flowers of chamomile contain terpenoids and flavonoids, which contribute to its medicinal properties. ${ }^{63}$ Seyyedi et $\mathrm{al}^{34}$ in a triple-blind, placebo-controlled randomized clinical trial found that chamomile mouth rinse was effective in reducing pain and burning sensation without producing any adverse side effects. The authors concluded that chamomile could be advised as an effective alternative treatment for RAS.

Ramos-e-Silva et $\mathrm{al}^{64}$ in their study concluded that the fluid extract from Chamomilla recutita had a good analgesic effect.

\section{Ginger (Zingiber officinale)}

Ginger is one of the most common herbs in traditional medicine. Some studies have also confirmed and demonstrated the anti-inflammatory effect of ginger. ${ }^{65-67}$ Haghpanah et a ${ }^{35}$ concluded from their study that bioadhesive film of ginger was capable of relieving pain in patients with RAS, but the change in the ulcer diameter, inflamed halo, and healing time were not significantly different from that of placebo.

\section{Triphala (Emblica officinalis, Terminalia bellirica, Terminalia chebula)}

Triphala has been a boon for oral and systemic health. Sen et $\mathrm{a}^{36}$ in a detailed review of has mentioned Triphala as antiplaque, antifungal, antiulcer because of the naturally present tannins and phenolic compounds. When used as a mouthwash, it forms a biofilm and due to its antioxidant activity, it protects the gums and oral mucosa from free radicals. It can also be a potential antiulcer medicament. Mohanpriya and Ramaswamy ${ }^{68}$ found that Triphala when mixed with honey and applied to aphthous ulcers of the mouth helps in the healing of the ulcers.

\section{Neem (Azadirachta indica)}

The phytochemical constituents of Azadirachta indica (neem) are nimbidin, nimbin, nimbolide, Azadirachtin, gallic acid, epicatechin, catechin, and margolone. All of these constituents exhibit a potent antibacterial activity. Traditionally, neem has been used for the treatment of inflammation, infections, fever, skin diseases, and dental problems. ${ }^{69}$ Lahankar et $\mathrm{al}^{37}$ in their study used "Haridradi Tail" a medicated oil preparation containing Curcuma longa, Azadirachta indica, Glycyrrhiza glabra, Sesamum indicum, and Nelumbo nucifera for the management of RAS. The preparation was found to be highly effective in providing symptomatic relief for ulcers on buccal mucosa, palate and enlargement of lymph nodes.

\section{Conclusion}

The review gives us a clear understanding that the naturally occurring constituents of medicinal herbs are definitely able to resolve oral ulcers irrespective of their etiology and prevent their recurrence. The healing ability of these herbs besides stepping up the immunity is responsible for their unmatched ability to cure the disease holistically. The use of this readily available, natural and safe resource as a part of dental practice definitely holds great potential for a "natural and green dental practice." Although the majority of studies have been conducted on RAUs, few have also shown efficacy in oral mucositis patients undergoing chemotherapy and traumatic ulceration. Due to the lack of sufficient clinical trials, we cannot still pinpoint the best herb to cure oral ulcers, but we are certainly on the way to herbalism in dentistry.

This review might provide the dentists a rich source and a road map for herbal alternatives for the treatment of oral ulcers in their practice and also a baseline for the researchers to carry on further research and to bridge the gaps between clinical and experimental dentistry.

\section{Conflict of Interest}

None declared. 


\section{References}

1 Porter SR, Leao JC. Review article: oral ulcers and its relevance to systemic disorders. Aliment Pharmacol Ther 2005;21(4):295-306

2 Subiksha PS. Various remedies for recurrent aphthous ulcer - a review. J Pharm Sci Res 2014;6(6):251-253

3 Dellinger TM, Livingston HM. Aspirin burn of the oral cavity. Ann Pharmacother 1998;32(10):1107

4 Parry J, Porter S, Scully C, Flint S, Parry MG. Mucosal lesions due to oral cocaine use. Br Dent J 1996;180(12):462-464

5 Scully C. Clinical practice. Aphthous ulceration. N Engl J Med 2006;355(2):165-172

6 Chattopadhyay A, Shetty KV. Recurrent aphthous stomatitis. Otolaryngol Clin North Am 2011;44(1):79-88

7 Natah SS, Konttinen YT, Enattah NS, Ashammakhi N, Sharkey KA, Häyrinen-Immonen R. Recurrent aphthous ulcers today: a review of the growing knowledge. Int J Oral Maxillofac Surg 2004;33(3):221-234

8 Borrelli F, Izzo AA. The plant kingdom as a source of anti-ulcer remedies. Phytother Res 2000;14(8):581-591

9 Ship JA. Recurrent aphthous stomatitis. An update. Oral Surg Oral Med Oral Pathol Oral Radiol Endod 1996;81(2):141-147

10 Gavanji S, Larki B, Bakhtari A. The effect of extract of Punica granatum var. pleniflora for treatment of minor recurrent aphthous stomatitis. Integr Med Res 2014;3(2):83-90

11 Jiang XW, Zhang Y, Zhu YL, et al. Effects of berberine gelatin on recurrent aphthous stomatitis: a randomized, placebo-controlled, double-blind trial in a Chinese cohort. Oral Surg Oral Med Oral Pathol Oral Radiol 2013;115(2):212-217

12 Dosani MA, Sakarkar DM, Kosalge SB, Shafiq S. Formulation development and evaluation of unit moulded herbal semisolid jelly useful in treatment of mouth ulcer. Int J Pharm Tech Res 2011;3(3):1705-1713

13 Shaikh R, Raj Singh TR, Garland MJ, Woolfson AD, Donnelly RF. Mucoadhesive drug delivery systems. J Pharm Bioallied Sci 2011;3(1):89-100

14 Pandharipande R, Chandak R, Sathawane R. Lanjekar A, Gaikwad R, Khandelwal V, Kurawar K. To evaluate efficiency of curcumin and honey in patients with recurrent aphthous stomatitis: a randomized clinical controlled trial. Int J Res Rev 2019;6(12):449-455

15 Daddy S, Izzaty N, Khalik B, Taib H, Pohchi A, Hassan A. Novel material in the treatment of minor oral recurrent aphthous stomatitis. Int Med J 2013;20:392-394

16 Manifar S, Obwaller A, Gharehgozloo A, Boorboor S, Kordi R, Akhondzadeh S. Curcumin gel in the treatment of minor Aphthous ulcer: a randomized, placebo-controlled trial. Faslnamah-i Giyahan-i Daruyi 2012;11:1-6

17 Arun P, Sagayaraj A, Mohiyuddin M, Santosh D. Role of turmeric extract in minimising mucositis in patients receiving radiotherapy for head and neck squamous cell cancer: a randomised, placebo-controlled trial. J Laryngol Otol 2020:1-6. Doi: 10.1017/S0022215120000316

18 Rao S, Dinkar C, Vaishnav LK, et al. The Indian spice turmeric delays and mitigates radiation-induced oral mucositis in patients undergoing treatment for head and neck cancer: an investigational study. Integr Cancer Ther 2014;13(3):201-210

19 Bhalang K, Thunyakitpisal P, Rungsirisatean N. Acemannan, a polysaccharide extracted from Aloe vera, is effective in the treatment of oral aphthous ulceration. J Altern Complement Med 2013;19(5):429-434

20 Babaee N, Zabihi E, Mohseni S, Moghadamnia AA. Evaluation of the therapeutic effects of Aloe vera gel on minor recurrent aphthous stomatitis. Dent Res J (Isfahan) 2012;9(4):381-385
21 Giroh VR, Hebbale M, Mhapuskar A, Hiremutt D, Agarwal P. Efficacy of aloe vera and triamcinolone acetonide $0.1 \%$ in recurrent aphthous stomatitis: a preliminary comparative study. J Indian Acad Oral Med Radiol 2019;31:45-50

22 Mansour G, Ouda S, Shaker A, Abdallah HM. Clinical efficacy of new aloe vera- and myrrh-based oral mucoadhesive gels in the management of minor recurrent aphthous stomatitis: a randomized, double-blind, vehicle-controlled study. J Oral Pathol Med 2014;43(6):405-409

23 Martin MD, Sherman J, van der Ven P, Burgess J. A controlled trial of a dissolving oral patch concerning glycyrrhiza (licorice) herbal extract for the treatment of aphthous ulcers. Gen Dent 2008;56(2):206-210

24 Halim DS, Mahanani ES, Saini R, Omar M, Ibrahi NR, Alam MK. A comparison study on the effectiveness of local honey and salicylate gel for treatment of minor recurrent aphthous stomatitis. Int Med J 2013;20:770-772

25 El-Haddad SA, Asiri FY, Al-Qahtani HH, Al-Ghmlas AS. Efficacy of honey in comparison to topical corticosteroid for treatment of recurrent minor aphthous ulceration: a randomized, blind, controlled, parallel, double-center clinical trial. Quintessence Int 2014;45(8):691-701

26 Mishra L, Nayak G. Effect of flavored (honey and tulsi) ice chips on reduction of oral mucositis among children receiving chemotherapy. Int J Pharm Sci Rev Res 2017;43(1):25-28

27 Mohamed SS, Al-Douri AS. The effect of honey on the healing of oral ulcers (clinical study)Al- Rafidain. DentJ 2008;8(2):157-160

28 Motallebnejad M, Akram S, Moghadamnia A, Moulana Z, Omidi S. The effect of topical application of pure honey on radiation-induced mucositis: a randomized clinical trial. J Contemp Dent Pract 2008;9(3):40-47

29 Arafa MG, Ghalwash D, El-Kersh DM, Elmazar MM. Propolisbased niosomes as oromuco-adhesive films: a randomized clinical trial of a therapeutic drug delivery platform for the treatment of oral recurrent aphthous ulcers. Sci Rep 2018;8(1):18056

30 Samet N, Laurent C, Susarla SM, Samet-Rubinsteen N. The effect of bee propolis on recurrent aphthous stomatitis: a pilot study. Clin Oral Investig 2007;11(2):143-147

31 Shrivastava R, John GW. Treatment of aphthous stomatitis with topical alchemilla vulgaris in glycerine. Clin Drug Investig 2006;26(10):567-573

32 Khozeimeh F, Saberi Z, Tavangar A, Badi FF. Effect of herbal Echinacea on recurrent minor oral aphthous ulcer. Open Dent J 2018;12:567-571

33 Guintu FZ, Chua AH. Effectivity of guava leaves (Psidium guajava) as mouthwash for patients with aphthous ulcers. Philipp J Otolaryngol Head Neck Surg. 2013;28(2):8-13

34 Seyyedi SA, Sanatkhani M, Pakfetrat A, Olyaee P. The therapeutic effects of chamomilla tincture mouthwash on oral aphthae: a randomized clinical trial. J Clin Exp Dent 2014;6(5):e535-e538

35 Haghpanah P, Moghadamnia AA, Zarghami A, Motallebnejad M. Muco-bioadhesive containing ginger officinal e extract in the management of recurrent aphthous stomatitis: a randomized clinical study. Caspian J Intern Med 2015;6(1):3-8

36 SenS, Sen S, Sharma S. Triphala: A Boon in Oral and Systemic Health. J Dent Oral Biol. 2017; 2(1): 1024.Subapriya R, Nagini S. Medicinal properties of neem leaves: A Review. Curr Med Chem Anticancer Agents 2005;5(2):149:14-6

37 Lahankar M, Magar V, Dwivedi P. Management of 'Mukhapaka' by 'Haridradi Tail' w.s.r. to recurrent aphthous ulcer. Int J AYUSH 2013;2(1):119-124 
38 Phua DH, Zosel A, Heard K. Dietary supplements and herbal medicine toxicities-when to anticipate them and how to manage them. Int J Emerg Med 2009;2(2):69-76

39 Shaikh S, Shete A, Doijad R. Formulation and evaluation pharmaceutical aqueous gel of powdered guava leaves for mouth ulcer treatment. PharmaTutor 2018;6(4):32-38

40 Heyam SA, Rasool BKA. Propolis buccal paste in treatment of aphthous ulceration: formulation and clinical evaluation. Asian J Pharm Clin Res. 2011;4(4):29-33

41 Thorat S, Sarvagod M, Kulkarni V, Hosmani H. Treatment of mouth ulcer by Curcumin loaded thermoreversible mucoadhesive gel. Int J Pharm Pharm Sci 2015;7(10):399-402

42 Deshmukh RA, Bagewadi AS. Comparison of effectiveness of curcumin with triamcinolone acetonide in the gel form in treatment of minor recurrent aphthous stomatitis: a randomized clinical trial. Int J Pharm Investig 2014;4(3):138-141

43 Francis M, Williams S. Effectiveness of Indian turmeric powder with honey as complementary therapy on oral mucositis: a nursing perspective among cancer patients in Mysore. Nurs J India 2014;105(6):258-260

44 Normando AGC, de Menêses AG, de Toledo IP, et al. Effects of turmeric and curcumin on oral mucositis: a systematic review. Phytother Res 2019;33(5):1318-1329

45 Reynolds T, Dweck AC. Aloe vera leaf gel: a review update. J Ethnopharmacol 1999;68(1-3):3-37

46 Vogler BK, Ernst E. Aloe vera: a systematic review of its clinical effectiveness. Br J Gen Pract 1999;49(447):823-828

47 Rezazadeh F, Moshaverinia M, Motamedifar M, Alyaseri M. Assessment of anti HSV-1 activity of aloe vera gel extract: an in vitro study. J Dent (Shiraz) 2016;17(1):49-54

48 Leiva-Cala C, Lorenzo-Pouso AI, Centenera-Centenera B, et al. Clinical efficacy of an Aloe Vera gel versus a $0.12 \%$ chlorhexidine gel in preventing traumatic ulcers in patients with fixed orthodontic appliances: a double-blind randomized clinical trial. Odontology 2020;108(3):470-478

49 Burgess JA, van der Ven PF, Martin M, Sherman J, Haley J. Review of over-the-counter treatments for aphthous ulceration and results from use of a dissolving oral patch containing glycyrrhiza complex herbal extract. J Contemp Dent Pract 2008;9(3):88-98

50 Ghalayani P, Emami H, Pakravan F, Nasr Isfahani M. Comparison of triamcinolone acetonide mucoadhesive film with licorice mucoadhesive film on radiotherapy-induced oral mucositis: a randomized double-blinded clinical trial. Asia Pac J Clin Oncol 2017;13(2):e48-e56

51 Aslani A, Zolfaghari B, Fereidani Y. Design, formulation, and evaluation of a herbal gel contains melissa, sumac, licorice, rosemary, and geranium for treatment of recurrent labial herpes infections. Dent Res J (Isfahan) 2018;15(3):191-200

52 Messier C, Epifano F, Genovese S, Grenier D. Licorice and its potential beneficial effects in common oro-dental diseases. Oral Dis 2012;18(1):32-39

53 Moghadamnia AA, Motallebnejad M, Khanian M. The efficacy of the bioadhesive patches containing licorice extract in the management of recurrent aphthous stomatitis. Phytother Res 2009;23(2):246-250

54 Khosravi T, Mehrafarin A, Naghdibadi H, Hajiaghaee R, Khosravi E. Effect of methanol and ethanol application on yield of Echinacea purpurea L. in Karaj region. J Herb Drugs 2011;2:121-128

55 Wagner H. Herbal immunostimulants for the prophylaxis and therapy of colds and influenza. Eur J Herb Med. 1997;3:22-30

56 Jawad M, Schoop R, Suter A, Klein P, Eccles R. Safety and efficacy profile of Echinacea purpurea to prevent common cold episodes: a randomized, double-blind, placebo-controlled trial. Evid Based Complement Alternat Med 2012;2012:841315

57 Yu D, Yuan Y, Jiang L, et al. Anti-inflammatory effects of essential oil in Echinacea purpurea L. Pak J Pharm Sci 2013; 26(2):403-408

58 Gichki SA, Khawakhail AA, Kurd SA, Ahmed K, Raisani MA. Healing effects of natural honey on oral minor aphthous ulcers among dental patients in Quetta. PODJ 2012;32(3):412-415

59 Li A, Xuan H, Sun A, Liu R, Cui J. Preparative separation of polyphenols from water-soluble fraction of Chinese propolis using macroporous absorptive resin coupled with preparative high performance liquid chromatography. J Chromatogr B Analyt Technol Biomed Life Sci 2016;1012-1013:42-49

60 Münstedt K. Bee products and the treatment of blister-like lesions around the mouth, skin and genitalia caused by herpes viruses-a systematic review. Complement Ther Med 2019;43:81-84

61 Jaiarj P, Khoohaswan P, Wongkrajang Y, et al. Anticough and antimicrobial activities of Psidium guajava Linn. leaf extract. J Ethnopharmacol 1999;67(2):203-212

62 Thombre KP, Sharma D, Lanjewar M. Formulation and evaluation pharmaceutical aqueous gel of powdered Cordia dichotoma leaves with guava leaves. Am J Pharm Res. 2018;8(2):268-277

63 Srivastava JK, Shankar E, Gupta S. Chamomile: a herbal medicine of the past with bright future. Mol Med Rep 2010; 3(6):895-901

64 Ramos-e-Silva M, Ferreira AF, Bibas R, Carneiro S. Clinical evaluation of fluid extract of Chamomilla recutita for oral aphthae. J Drugs Dermatol 2006;5(7):612-617

65 White B. Ginger: an overview. Am Fam Physician 2007; 75(11):1689-1691

66 Bliddal H, Rosetzsky A, Schlichting P, et al. A randomized, placebo-controlled, cross-over study of ginger extracts and ibuprofen in osteoarthritis. Osteoarthritis Cartilage 2000;8(1):9-12

67 Sharma JN, Srivastava KC, Gan EK. Suppressive effects of eugenol and ginger oil on arthritic rats. Pharmacology 1994; 49(5):314-318

68 Mohanpriya M, Ramaswamy I. Amla - the wonder of Ayurvedic medicine. Int J Ayu Herb Med. 2012;2:828-834

69 Sharma P, Tomar L, Bachwani M, Bansal V. Review on Neem (Azadirachta indica): thousand problem one solution. Int Res J Pharm 2011;2:97-102 